\title{
MENINGKATKAN HASIL BELAJAR SISWA DENGAN MENGGUNAKAN MODEL PEMBELAJARAN KOOPERATIF TIPE STUDENT TEAM ACHIEVEMENT DIVISIONS (STAD) MATA PELAJARAN IPS POKOK BAHASANKENAMPAKAN ALAM DAN BUDAYA DI KELAS IV SD NEGERI 055988 GUNUNG AMBAT TAHUN PEMBELAJARAN 2017/2018
}

\section{OLEH: \\ EDI SAHPUTRA (PGSD FKIP UNIVERSITAS KATOLIK SANTO THOMAS SU)}

\begin{abstract}
This study aims to describe the study of Classroom Action Research (PTK) using Student Team Achievement Divisions (STAD) learning model in IPS subjects in class IV SD Negeri 055988 Gunung Ambat. The research approach used is quantitative and qualitative approach, with the subject of research that is the fourth grade students of SD Negeri 055988 Gunung Ambat which amounts to 31 students. Data collection techniques used are observation and test.

The results of the research on the first cycle obtained the number of teacher observation points as much as 28 with a percentage of $56 \%$. Observation of student activity obtained by the number of points as much as 24 with percentage $48 \%$ and many complete student in accordance with value of Criterion Complete $(\mathrm{KKM})>65$ is counted 16 student with percentage 51,61\%, while many student which not finished in other word not reach Criteria Completeness (KKM) $<65$ is as many as 15 students with a percentage of $48.38 \%$. The average value of students in the first cycle is 59.83 while the number of students in classical completeness has not reached $75.00 \%$ is $51.61 \%$, then continued on cycle II. In the second cycle of teacher activity observation results obtained the number of teacher observation points as much as 39 percentage $78 \%$. Observation of student activity obtained by the number of points as much as 38 with percentage $76 \%$ and many complete student in accordance with value Criteria Completeness (KKM)> 65 is as many as 27 student with percentage $87 \%$, while many student which does not complete in other word does not reach Completeness Criterion KKM) $<65$ is as many as 4 students with $12.90 \%$ percentage. Based on the data analysis, it is concluded that the implementation of Student Team Achievement Divisions (STAD) learning model on IPS lesson with the subject of natural and cultural appearance in class IV SD Negeri 055988 Gunung Ambat Learning Year 2017/2018 has good categorization and learning outcomes increase.

The limitation of this study is the Student Team Achievement Division (STAD) model of learning is a model that creates a comfortable learning environment for students, so that teachers creativity is required in conveying learning.
\end{abstract}

Keywords: Learning outcomes, Student Team Achievement Divisions (STAD) Learning Models. 


\section{PENDAHULUAN \\ Latar Belakang Masalah}

Tujuan pendidikan adalah untuk menghantarkan manusia menuju alam kedewasaan yang sempurna lewat proses yang direncanakan dan diinginkan baik oleh dirinya maupun oleh masyarakat yang ada disekelilingnya. Akan tetapi pendidikan di Indonesia dihadapkan pada beberapa hal diantaranya, masalah pemerataan pendidikan, masalah mutu pendidikan, masalah relevansi dan masalah efisiensi serta efektivitas.

Salah satu permasalahan pendidikan yang dihadapi oleh bangsa Indonesia adalah rendahnya mutu pendidikan pada setiap jenjang dan satuan pendidikan. Secara umum penyelenggaraan pendidikan bertujuan untuk membentuk proses belajar, yaitu usaha untuk memperkenalkan seseorang pada sesuatu yang akan diketahuinya ataupun lingkungannya. Sekolah merupakan tempat pendidikan, tempat guru mengajar dan murid belajar, sehingga terjadilah proses belajar mengajar yang bertujuan untuk membangun manusia Indonesia seutuhnya seperti yang tercantum pada UU No. 20 Tahun 2003 tentang Sistem Pendidikan Nasional, BAB II Pasal 3 yang berbunyi :

Pendidikan Nasional berfungsi mengembangkan kemampuan dan membentuk watak serta peradaban bangsa yang bermartabat dalam rangka mencerdaskan kehidupan bangsa, bertujuan untuk berkembangnya potensi peserta didik agar menjadi manusia yang beriman dan bertakwa kepada Tuhan Yang Maha Esa, berakhlak mulia, sehat, berilmu, cakap, kreatif, mandiri, dan menjadi warga negara yang demokratis serta bertanggung jawab.

Pendidikan juga merupakan usaha atau kegiatan yang disengaja untuk membantu, membina, dan mengarahkan manusia mengembangkan segala kemampuannya yang dilaksanakan dan dikembangkan secara sistematis melalui proses pembelajaran yang terencana dengan baik. Proses pendidikan dilakukan sedemikian rupa supaya manusia dapat mempersiapkan diri dan mandiri mengatasi permasalahan-permasalahan kehidupan yang dihadapinya. Pembangunan pendidikan merupakan syarat mutlak bagi kelancaran pembangunan secara keseluruhan. Makna pendidikan disini tidaklah sekedar pemindahan ilmu pengetahuan, tetapi lebih luas lagi yaitu untuk menciptakan manusia yang berguna bagi diri sendiri maupun bagi masyarakat. Dalam meningkatkan hasil belajar siswa, telah banyak upaya-upaya untuk memperbaiki spek-aspek yang berkaitan dengan kegiatan pembelajaran. Tercakup dalam perbaikan itu adalah perbaikan terhadap tujuan, kurikulum, pelaksanaan pembelajaran, evaluasi juga terhadap kualifikasi guru. Upaya yang berkaitan dengan perbaikan tujuan dan kurikulum dilakukan setiap ada pemberlakuan perangkat kurikulum baru atau penyempurnaan terhadap kurikulum yang sedang diterapkan, seperti kurikulum Berbasis Kompetensi (KBK) lalu dilakukan perubahan terhadap Kurikulum Tingkat SatuanPengajaran (KTSP).

Terkait dengan pemaparan tentang pendidikan di atas, maka sangat erat hubungannya dengan belajar yang merupakan proses perubahan yaitu perubahan tingkah laku sebagai hasil dari interaksi lingkungannya dalam memenuhi kebutuhan hidupnya. Perubahan-perubahan tersebut akan nyata dalam seluruh aspek tingkah laku. Dengan demikian tujuan pengajaran tentu saja akan dapat 
tercapai jika siswa berusaha aktif untuk mencapainya. Belajar pada hakekatnya adalah suatu proses usaha yang dilakukan seseorang untuk memperoleh suatu perubahan tingkah laku yang baru secara keseluruhan, sebagai hasil pengalaman sendiri dalam interaksi dengan lingkungannya.

Sebagai seorang pendidik yang membantu siswa dalam proses belajar guru harus memahami fungsi dan tugasnya. Sejalan dengan tantangan global, peran dan tanggung jawab guru pada masa mendatang akan semangkin kompleks, sehingga menuntut guru untuk senantiasa melakukan berbagai peningkatan dan penyesuaian kemampuan professional. Guru harus lebih dinamis dan kreatif dalam mengembangkan proses pembelajaran. Salah satu usaha yang dapat di lakukan seorang guru dalam mengembangkan proses pembelajaran adalah dengan cara menggunakan model pembelajaran yang efektif.

Siswa merupakan komponen yang sangat penting dalam sistem pendidikan, serta orang yang memiliki potensi dasar, yang perlu dikembangkan melalui proses pendidikan. Salah satu cara agar anak memperoleh pendidikan yaitu dengan sekolah, sebab sekolah merupakan salah satu sarana untuk mendidik. Di sekolah siswa akan belajar banyak hal termasuk belajar ilmu pengetahuan. Didalam pembelajaran siswa harus dapat belajar secara aktif agar hasil belajar yang dicapai bisa optimal untuk mencapai hasil belajar yang optimal pengajar sebagai pengelola kelas harus mampu memberikan proses pembelajaran yang tepat, kreatif dan efektif dengan cara menerapkan model pembelajaran yang menarik minat siswa untuk belajar. Sebab model pembelajaran merupakan suatu keharusan untuk membekali siswa dengan kemampuan berpikir.

Pendidikan IPS adalah disiplin-disiplin ilmu sosial ataupun integrasi dari berbagai cabang ilmu sosial seperti: sosiologi, sejarah, geografi ekonomi dan antropologi yang mempelajari masalah-masalah sosial. Pembelajaran pendidikan IPS di sekolah bertujuan agar siswa paham dan menguasai konsep sosial, selain itu mata pelajaran IPS di sekolah juga bertujuan untuk mengembangkan potensi siswa agar peka terhadap masalah social yang terjadi di masyarakat, memiliki sikap mental positif terhadap perbaikan segala ketimpangan yang terjadi, dan trampil menghadapi setiap masalah yang terjadi sehari-hari baik yang menimpa dirinya sendiri maupun yang menimpa masyarakat.

Berdasarkan hasil observasi yang dilakukan oleh peneliti pada saat proses pembelajaran IPS maka peneliti menemukan beberapa kendala dalam proses pembelajaran adalah guru dalam proses pembelajaran masih menerapkan model pembelajaran yang kurang kreatif dan efektif, hal ini menyebabkan kurang aktifnya siswa dalam belajar siswa cenderung mengantuk, tidak pernah bertanya dan sering kali asik bermain dengan teman sebangkunya pada saat guru menjelaskan materi, selain itu guru juga kurang memotivasi siswa dan guru juga jarang memakai media atau alat peraga dalam proses pembelajaran karena sarana dan prasarana yang diberikan sekolah masih kurang dengan keadaan seperti ini kegiatan belajar mengajar menjadi tidak kondusif dan kurang menarik perhatian siswa. Minat belajar siswa menjadi berkurang.

Dari prolehan hasil observasi yang dilakukan oleh peneliti pada mata pelajaran IPS dengan materi kenampakan alam dan budaya di kelas IV SDN 055988 Gunung Ambat Tahun Pembelajaran 2016/2017 semester ganjil, diperoleh hasil belajar siswa sebagai berikut: 
Tabel 1.1

Hasil Nilai Mata Pelajaran IPS Kelas IVSDN 055988Gunung Ambat T.P 2016/2017

\begin{tabular}{|c|c|c|c|c|c|}
\hline \multirow[b]{2}{*}{ No } & \multirow[b]{2}{*}{ KKM } & \multirow[b]{2}{*}{ Nilai } & \multicolumn{2}{|c|}{ Banyak Siswa } & \multirow[b]{2}{*}{ Persentasi } \\
\hline & & & Tuntas & $\begin{array}{c}\text { Tidak } \\
\text { Tuntas }\end{array}$ & \\
\hline 1 & \multirow[b]{2}{*}{65} & $\geq 65$ & 13 & & $48 \%$ \\
\hline 2 & & $<65$ & & 14 & $52 \%$ \\
\hline \multicolumn{3}{|c|}{ Jumlah } & \multicolumn{2}{|c|}{27} & $100 \%$ \\
\hline
\end{tabular}

Sumber : Daftar nilai SiswaSDN 055988 Gunung Ambat Mata Pelajaran IPS pada Materi Kenampakan Alam dan Budaya

Berdasarkan Tabel diatas menunjukan bahwa pada semester ganjil tahun ajaran 2016/2017 di kelas IV mata pelajaran IPS dengan pokok bahasan kenampakan alam dan budaya, dari 27 siswa yang memperoleh nilai Kriteria Ketuntasan Minimum (KKM) sebanyak 13 siswa atau 48\%, dan jumlah siswa yang memperoleh nilai di bawah Kriteria Ketuntasan Minimum (KKM) adalah sebanyak 14 siswa atau $52 \%$.

Berdasarkan masalah yang telah ditemukan, peneliti mengambil salah satu model pembelajaran yang diharapkan dapat meningkatkan hasil belajar siswa yaitu dengan mengunakan model pembelajaran Kooperatif Tipe STAD. Menurut Istarani (2014: 55), model pembelajaran tipe ini merupakan salah satu tipe dari model pembelajaran kooperatif dengan menggunakan kelompok-kelompok kecil dengan jumlah anggota tiap kelompok 4-5 orang siswa secara heterogen. Diawali dengan penyampaian tujuan pembelajaran, penyampaian materi, kegiatan kelompok kuis, dan penghargaan kelompok.

Dari pendapat ahli di atas dapat disimpulkan bahwa model pembelajaran STAD dapat dijadikan alternatif untuk dapat meningkatkan hasil belajar siswa.

Berdasarkan uraian permasalahan di atas, maka peneliti tertarik untuk melakukan penelitian dengan judul "Meningkatkan Hasil Belajar Siswa dengan Menggunakan Model Pembelajaran Kooperatif Tipe Student Team Achievement Divisions(STAD) Mata Pelajaran IPS Materi Kenampakan Alam dan Budayadi Kelas IV SD Negeri 055988 Gunung AmbatTahun Pembelajaran 2017/2018".

Identifikasi Masalah

Dari latar belakang masalah di atas masalah-masalah pembelajaran di kelas IV SDNegeri055988 Gunung AmbatTahun Pembelajaran 2017/2018 yang dapat diidentifikasi sebagai berikut:

1. Hasil belajar siswa yang rendah pada mata pelajaran Ilmu Pengetahuan Sosial (IPS) di kelas IV

2. Model pembelajaran kurang kreatif dan efektif.

3. Guru jarang memakai media/alat praga pada saat mengajar.

4. Proses belajar mengajar yang kurang kondusif.

5. Sarana dan prasarana yang kurang diberikan oleh sekolah.

\section{Batasan Masalah}


Berdasarkan uraian pada latar belakang dan identifikasi masalah di atas, perlu dilakukan pembatasan masalah agar penelitian ini lebih terarah dan terfokus pada masalah yang akan diteliti. Oleh karena itu masalah penelitian ini dibatasi pada hasil belajar IPS siswa dengan menggunakan model pembelajaran kooperatif tipe Student Team Achievement Divisions (STAD) padapokok bahasan kenampakan alam dan budaya di kelas IV SDN 055988 Gunung Ambat Tahun Pembelajaran 2017/2018.

\section{Rumusan Masalah}

Berdasarkan pada latar belakang, identifikasi dan batasan masalah yang dipaparkan di atas, maka rumusan masalah dalam penelitian ini adalah sebagai berikut :

1. Bagaimana pelaksanaan model pembelajaran kooperatif tipe Student Team Achievement Divisions (STAD) pada mata pelajaran IPS pokok bahasan kenampakkan alam, dan budaya di kelas IV SDN 055988 Gunung Ambat tahun pembelajaran 2017/2018?

2. Apakah dengan menggunakan model pembelajaran kooperatif tipe Student Team Achievement Divisions (STAD) dapat meningkatkan hasil belajar IPS siswa pada pokok bahasan kenampakan alamdan budaya di kelas IV SDN 055988 Gunung Ambat tahun pembelajaran 2017/2018?

\section{Tujuan Penelitian}

Adapun tujuan penelitian ini adalah :

1. Untuk mengetahui bagaimana pelaksanaan model pembelajaran kooperatif tipe Student Team Achievement Divisions (STAD) pada mata pelajaran IPS pokok bahasan kenampakan alam, dan budayadi kelas IV SDN 055988 Gunung Ambat tahun pembelajaran 2017/2018.

2. Untuk meningkatkan hasil belajar IPS siswa dengan menggunakan model pembelajaran kooperatif tipe Student Team Achievement Divisions (STAD)pada pokok bahasan kenampakan alam, dan budayadi kelas IV SDN 055988 Gunung Ambat tahun pembelajaran 2017/2018.

\section{Manfaat Penelitian}

Penelitian ini bermaksud untuk memperoleh data sebagai informasi yang diperoleh dari penerapan model pembelajaran kooperatif tipe Student Team Achievement Divisions (STAD) untuk meningkatkan hasil belajar IPS siswa kelas IV SDN 055988 Gunung Ambat.

Manfaat yang diharapkan dari penelitian tindakan ini adalah sebagai berikut :

1. Manfaat Teoritis

Hasil penelitian ini dapat memperkaya khasanah ilmu pengetahuan khususnya kajian bahasan kenampakan alam, dan budaya.

2. Manfaat Praktis
a. Bagi Sekolah
b. Bagi Guru
c. Bagi Peserta Didik
d. Bagi Peneliti

\section{METODOLOGI PENELITIAN Metode Penelitian}


Adapun jenis penelitian yang digunakan oleh peneliti adalah Penelitian Tindakan Kelas (PTK) dengan menggunakan model pembelajaran Student Team Achievement Divisions (STAD).

Aqib (2014: 3) menyatakan, "Penelitian Tindakan Kelas (PTK) merupakan penelitian yang dilakukan oleh seorang guru di dalam kelasnya sendiri melalui refleksi diri, dengan tujuan untuk memperbaiki dan meningkatkan kinerjanya sebagai guru sehingga hasil belajar siswa meningkat". Sementara Arikunto (2012: 1-2) menyatakan, "Penelitian tindakan kelas adalah penelitian yang memaparkan terjadinya sebab-akibat dari perlakuan, sekaligus memaparkan apa saja yang terjadi ketika perlakuan diberikan, dan memaparkan seluruh proses sejak awal pemberian perlakuan sampai dengan dampak-dampak dari perlakuan tersebut". SedangkanTampubolon (2014: 19) menyatakan, "Penelitian Tindakan Kelas (PTK) adalah penelitian yang dilakukan oleh pendidik/calon pendidik di dalam kelasnya sendiri secara kolaboratif/partisipasi untuk memperbaiki kinerja pendidik menyangkut kualitas proses pembelajaran, dan meningkatkan hasil belajar peserta didik, baik dari aspek akademik maupun nonakademik, melalui tindakan reflektif dalam bentuk siklus (daur ulang).

Berdasarkan beberapa pendapat para ahli di atas dapat disimpulkan bahwa Penelitian Tindakan Kelas (PTK) merupakan kegiatan penelitian yang dilakukan pendidik yang difokuskan pada situasi pembelajaran di dalam kelas dan memiliki tujuan untuk memperbaiki dan meningkatkan suatu hasil pembelajaran siswa. Penelitian Tindakan Kelas (PTK) merupakan kegiatan yang mendorong guru untuk berani bertindak dan berpikir kritis dalam mengembangkan teori dan rasional bagi guru yang bersangkutan. Selain itu, melalui Penelitian Tindakan Kelas (PTK) guru diberi tanggung jawab mengenai pelaksanaan tugasnya secara profesional.

\section{Tempat dan Waktu Penelitian}

\section{Tempat Penelitian}

Penelitian ini dilaksanakan di SDN 055988 Gunung Ambat. Adapun pemilihan tempat tersebut sebagai lokasi penelitian didasari pertimbangan sebagai berikut:

1. Masih rendahnya hasil belajar siswa pada mata pelajaran Ilmu Pengetahuan Sosial (IPS) dengan pokok bahasan kenampakan alamdan budaya di kelas IV SDN 055988 Gunung Ambat.

2. Jumlah siswa di SDN 055988 Gunung Ambat cukup memadai untukdijadikan sampel penelitian.

3. Belum ada peneliti yang melakukan penelitian dengan menerapkan model pembelajaran kooperatif tipe Student Team Achievement Divisions (STAD).

\section{Waktu Penelitian}

Penelitian Tindakan Kelas (PTK) ini dilaksanakan dalam dua minggu atau dua kali pertemuan. Penelitian dilaksanakan pada semester ganjil tahun pembelajaran 2017/2018.

\section{Subjek Penelitian}

Subjek penelitian adalah siswa yang menjadi sasaran pelaksanaan tindakan yaitu siswa kelas IV SDN 055988 Gunung Ambat tahun pembelajaran 2017/2018 dengan jumlah siswa 31 orang yang terdiri dari 14 siswa laki-laki dan 17 siswa perempuan. 


\section{Jenis dan Sumber Data}

\section{Jenis data}

Data yang digunakan oleh peneliti dalam penelitian ini adalah data kuantitatif dan kualitatif.

a. Data Kuantitatif

Data kuantitatif pada penelitian ini berisi nilai hasil belajar siswa yang diperoleh melalui tes yang digunakan untuk mengukur kemampuan kognitif siswa. Nilai hasil belajar tersebut diperoleh dari hasil prates yang diberikan sebelum memuli pembelajaran pada siklus I dan II, serta postes yang dilaksanakan pada akhir pembelajaran siklus I dan II

b. Data Kualitatif

Data kualitatif dalam penelitian ini berupa data hasil pengamatan atau hasil pelaksanaan pembelajaran pada saat berlangsungnya proses belajar mengajar. Data tersebut berupa hasil pengamatan aktivitas guru dan siswa yang diperoleh melalui lembar pengamatan.

\section{Sumber Data}

Sugiyono (2015: 193) menyatakan, "Dilihat dari sumber datanya, maka pengumpulan data dapat menggunakan sumber primer, dan sumber sekunder". Sumber primer adalah sumber data yang langsung memberikan data kepada pengumpul data, dan sumber sekunder merupakan sumber yang tidak langsung memberikan data kepada pengumpul data, misalnya lewat orang lain atau lewat dokumen. Sumber yang dipakai dalam penelitian ini adalah sumber primer dan sekunder yakni sebagai berikut.

a. Informasi atau narasumber, yaitu guru kelas IV dan siswa kelas IV SDN 055988 Gunung Ambat.

b. Tempat berlangsungnya aktivitas pembelajaran Ilmu Pengetahuan Sosial (IPS) yaitu SDN 055988 Gunung Ambat.

c. Daftar nilai mata pelajaran Ilmu Pengetahuan Sosial (IPS) yaitu SDN 055988 Gunung Ambat.

\section{Alat Pengumpulan Data}

Teknik pengumpulan data merupakan langkah yang paling strategis dalam penelitian, karena tujuan utama dari penelitian adalah mendapatkan data. Teknik pengumpulan data yang digunakan oleh peneliti untuk menghitung hasil belajar siswa dalam penelitian ini adalah tes dan observasi.

\section{Tes}

Tes digunakan untuk mengukur sejauhmana seorang siswa telah menguasai pelajaran yang disampaikan.

Menurut Jihad (2012: 67), tes merupakan himpunan pertanyaan yang harus dijawab, harus ditanggapi, atau tugas yang harus dilaksanakan oleh orang yang dites.

Tes hasil belajar Ilmu Pengetahuan Sosial (IPS) dalam penelitian ini adalah berupa tes pilihan berganda yang disusun berdasarkan kisi-kisi instrumen yang telah disusun. Tes pilihan berganda ini dilaksanakan setelah proses pembelajaran Ilmu Pengetahuan Sosial (IPS) berakhir pada setiap siklus untuk 
memperoleh data tentang hasil belajar siswa pada mata pelajaran Ilmu Pengetahuan Sosial (IPS).

\section{Observasi}

Observasi adalah sebagai tehnik pengumpulan data dengan jalan mengadakan pengamatan terhadap kegiatan yang sedang berlangsung kegiatan tersebut bisa berkenaan dengan cara guru mengajar, siswa belajar belajar, kepala sekolah yang memberikan pengarahan Sukamadinata (2015: 220).

Untuk mengukur aktivitas guru dan siswa peneliti menggunakan lembar observasi. Teknik observasi merupakan teknik pengumpulan data dengan melakukan pengamatan pada objek penelitian. Pada penelitian ini melibatkan peneliti dan guru sebagai observer. Proses observasi dilakukan dengan mengacu pada pedoman observasi yang telah disusun. Aktivitas guru dan siswa diamati untuk mendapatkan seberapa besar pengaruh proses pembelajaran Ilmu Pengetahuan Sosial (IPS) dengan menggunakan model pembelajaran Student Team Achievement Divisions (STAD) dapat mempengaruhi aktivitas guru dan siswa dan apakah kegiatan yang dilakukan telah sesuai dengan yang direncanakan.

\section{Uji Validitas Instrumen}

Validitas soal digunakan untuk mengetahui valid tidaknya soal yang akan diujikan sehingga soal yang dinyatakan valid layak untuk diujikan. Validitas merupakan derajad ketetapan antara data yang terjadi pada objek penelitian dengan daya yang dapat dilaporkan oleh peneliti (Sugiyono, 2015: 267)

Uji validitas ada penelitian ini menggunakan teknik uji validitas product moment dengan mengkorelasikan antara skor yang didapat siswa pada suatu butir soal dengan skor total yang didapat. Rumus yang digunakan:

$r_{x y}=\frac{\mathrm{N} \sum \mathrm{XY}-\left(\sum \mathrm{X}\right)\left(\sum Y\right)}{\sqrt{\left\{N \sum X^{2}-\left(\sum X\right)^{2}\right\}\left\{N \sum Y^{2}-\left(\sum Y\right)^{2}\right\}}}$ Jihad dan Haris

(2012:180)

Keterangan :

$\mathrm{r}_{\mathrm{xy}} \quad$ :Koefisien korelasi antara variabel $\mathrm{X}$ dan $\mathrm{Y}$

$\mathrm{N} \quad$ :Banyaknya peserta tes

$\mathrm{X} \quad$ :Nilai hasil uji coba

Y :Nilai rata-rata harian

Interprestasi terhadap nilai koefisien korelasi $\mathrm{r}_{\mathrm{xy}}$ digunakan kriteria berikut ini:

Tabel 3.5 Interpensi terhadap Koefisien Korelasi

\begin{tabular}{|c|c|}
\hline Koefisien Korelasi & Makna \\
\hline $0,80<\mathrm{r}_{\mathrm{xy}} \leq 1.00$ & Sangat tinggi \\
\hline $0,60<\mathrm{r}_{\mathrm{xy}} \leq 0,80$ & Tinggi \\
\hline $0,40<\mathrm{r}_{\mathrm{xy}} \leq 0,60$ & Cukup \\
\hline $0,20<\mathrm{r}_{\mathrm{xy}} \leq 0,40$ & Rendah \\
\hline $\mathrm{r}_{\mathrm{xy}} \leq 0,20$ & Sangat rendah \\
\hline
\end{tabular}

\section{Uji Reliabilitas Instrumen Soal}

Reliabilitas soal merupakan ukuran yang menyatakan tingkat kejenjangan atau kekonsistenan suatu soal tes. Untuk mengukur tingkat kejenjagan soal ini digunakan perhitungan Alpha Crombach. Menurut Arikunto(2012: 115), untuk 
menguji reliabilitas tes pada penelitian ini yang digunakan adalah KR-20 dengan rumus sebagai berikut:

Dimana:

$$
\mathbf{r}_{11}=\left(\frac{n}{n-1}\right)\left(\frac{s 2-\sum p q}{s 2}\right)
$$

$\mathrm{r}_{11}=$ reliabilitas tes secara keseluruhan

$\mathrm{p} \quad=$ proporsi subjek yang menjawab item dengan benar

$\mathrm{q}=$ proporsi subjek yang menjawab item dengan salah $(\mathrm{q}=1-\mathrm{p})$

$\sum p q=$ jumlah hasil perkalian antara $\mathrm{p}$ dan $\mathrm{q}$

$\mathrm{n} \quad=$ banyaknya item

$\mathrm{s} \quad=$ standar deviasi dari tes (standar deviasi adalah akar varians)

sebagai berikut:

Interprestasi terhadap nilai koefisien korelasi $r_{11}$ digunakan kriteria

$\mathrm{r}_{11} \leq 0,20 \quad=$ reliabilitas sangat rendah

$0,20<\mathrm{r}_{11} \leq 0,40=$ reliabilitas rendah

$0,40<\mathrm{r}_{11} \leq 0,70=$ reliabilitas sedang

$0,70<r_{11} \leq 0,90=$ reliabilitas tinggi

$0,90<r_{11} \leq 1,00=$ reliabilitas sangat tinggi

\section{Metode Analisis Data}

Analisis data adalah proses mencari dan menyusun secara sistematis data yang diperoleh dari hasil wawancara, catatan lapangan, sehingga dapat mudah dipahami, dan temuannya dapat diinformasikan kepada orang lain, analisis data dilakukan dengan mengorganisasikan data, menjabarkan ke dalam unit-unit, melakukan sintesa, menyusun ke dalam pola, memilih mana yang penting yang akan dipelajari, dan membuat kesimpulan yang dapat diceritakan kepada orang lain (Sugiyono, 2016: 244).

Analisis data ini lakukan untuk mengetahui berhasil tidaknya penelitian ini. Untuk menganalisis data yang diperoleh dari hasil tes dapat digunakan rumus berikut:

\section{Ketuntasan Individu}

Siswa yang dikatakan tuntas belajarnya (ketuntasan individual) yaitu apabila siswa memperoleh hasil belajar yang mencapai KKM yang ditentukan sekolah yaitu 65. Untuk menghitung ketuntasan hasil belajar siswa (individu) maka dapat digunakan rumus sebagai berikut:

$\mathrm{KB}=\frac{\boldsymbol{T}}{\boldsymbol{T} t} \times 100 \%$ (Trianto, 2009: 241)

Dimana: $\quad \mathrm{KB}$ : Ketuntasan belajar

$\mathrm{T}$ : Jumlah skor yang diperoleh siswa

$\mathrm{Tt}$ : Jumlah skor total

Hasil penghitungan disesuaikan dengan kriteria ketuntasan belajar siswa yang dikelompokkan ke dalam dua kategori tuntas dan tidak tuntas. Dengan kriteria sebagai berikut:

Tabel 3.8 Kriteria Ketuntasan Hasil Belajar Siswa

\begin{tabular}{|c|c|}
\hline Kriteria ketuntasan & Kualifikasi \\
\hline$\geq 65$ & Tuntas \\
\hline$<65$ & Tidak tuntas \\
\hline
\end{tabular}

Ketuntasan Klasikal

Volume: 1 No. 1 Juli 2018

JURNAL ILMIAH AQUINAS TERBIT JULI DAN JANUARI SETIAP TAHUNNYA 
Trianto (2011: 241) menyatakan, "Suatu kelas dikatakan tuntas belajarnya (ketuntasan klasikal) jika dalam kelas tersebut terdapat $\geq 85 \%$ siswa yang telah tuntas belajarnya". Untuk menghitung ketuntasan belajar siswa secara klasikal, dapat dihitung melalui rumus sebagai berikut:

$\mathbf{P}=\frac{\sum \text { siswayangtuntasbelajar }}{\sum \text { siswa }} \times 100 \%$ (Aqid dkk, 2014:

41)

Dimana: $\quad$ P : Ketuntasan klasikal hasil obserfasi

Tabel 3.9 Kriteria Tingkat Keberhasilan Belajar Siswa Dalam \%

\begin{tabular}{|c|c|}
\hline Tingkat Keberhasilan (\%) & Arti \\
\hline$>80 \%$ & Sangat tinggi \\
\hline $60-76 \%$ & Tinggi \\
\hline $40-59 \%$ & Sedang \\
\hline $20-39 \%$ & Rendah \\
\hline$<20 \%$ & Sangat rendah \\
\hline
\end{tabular}

Hasil analisis ini digunakan sebagai bahan refleksi untuk melaksanakan perancanaan lanjut dalam siklus berikutnya. Hasil analisis juga dijadikan sebagai bahan refleksi dalam memperbaiki rancangan pembelajaran.

\section{Rata-Rata Hasil Belajar Siswa}

Untuk mengetahui peningkatan hasil belajar siswa maka dapat digunakan rumus mencari rata-rata yaitu:

$\mathbf{X}=\frac{\sum \mathbf{X}}{\sum \mathbf{N}}$ (Aqib dkk,

2014: 40)

Dimana: $\quad X$ : Nilai rata-rata

$\sum \mathrm{X}$ : Jumlah semua nilai siswa

$\sum \mathrm{N}$ : Jumlah siswa

\section{Penilaian Aktivitas Guru}

Untuk mengetahui pelaksanaan pembelajaran pada guru, dapat di gunakan rumus sebagai berikut:

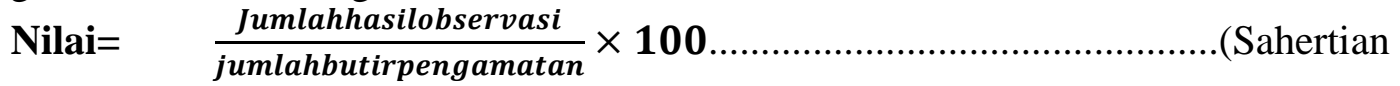
2010: 61)

Hasil penilaian pelaksanaan aktivitas guru dapat digunakan kriteria Sahertian (2010: 61) sebagai berikut:

Tabel 3.10Kriteria Penilaian Dalam PelaksanaanPembelajaran Aktivitas Guru

\begin{tabular}{|c|c|}
\hline Kriteria Penilaian & Keterangan \\
\hline $\mathrm{A}=81-100 \%$ & Baik Sekali \\
\hline $\mathrm{B}=61-80 \%$ & Baik \\
\hline $\mathrm{C}=41-60 \%$ & Cukup \\
\hline $\mathrm{D}=21-40 \%$ & Kurang \\
\hline $\mathrm{E}=0-20 \%$ & Sangat Kurang \\
\hline
\end{tabular}

\section{Penilaian Aktivitas Siswa}

Untuk menghitung hasil pelaksanaan pembelajaran pada siswa, dapat digunakan rumus sebagai berikut: 
Nilai siswa $=\frac{\text { skorperolehan }}{\text { skormaksimum }} \times 100 \%$ .. (Jihad \& Haris, 2012: 130)

Kriteria penilaian aktivitas siswa dalam pelaksanaan pembelajaran dapat digunakan kriteria Jihad dan Haris (2013: 131) sebagai berikut:

Tabel 3.11 Kriteria Penilaian PelaksanaanPembelajaran Aktivitas Siswa

\begin{tabular}{|c|c|}
\hline Nilai & Kriteria \\
\hline $\mathrm{A}=90-100$ & Sangat baik \\
\hline $\mathrm{B}=70-89$ & Baik \\
\hline $\mathrm{C}=50-69$ & Cukup \\
\hline $\mathrm{D}=30-49$ & Kurang \\
\hline $\mathrm{E}=10-29$ & Sangat kurang \\
\hline
\end{tabular}

\section{Indikator Keberhasilan Penelitian}

Tampubolon (2014: 35) menyatakan, "Penelitian tindakan kelas diasumsikan berhasil bila dilakukan tindakan perbaikan kualitas pembelajaran, maka akan berdampak terhadap perbaikan perilaku siswa dan hasil belajar. Menurut urutan indikator secara logika disusun menjadi:

1. Indikator keberhasilan kualitas proses pembelajran minimal "baik" (indikator ini untuk tujuan umum dari penelitian).

2. Indikator keberhasilan hasil belajar secara klasikal minimal $75 \%$ dari jumlah siswa yang mencapai KKM yang ditetapkan".

Catatan: Indikator 1 dan 2 menggunkan tabel konversi nilai (tabel 3.12)

Tabel 3.12 Konvensi Nilai (Tampubolon, 2014: 35)

\begin{tabular}{|c|c|c|}
\hline Interval Nilai & Kategori & Makna \\
\hline $81-100$ & A & Sangat baik \\
\hline $60-80$ & B & Baik \\
\hline $41-60$ & C & Cukup baik \\
\hline $21-40$ & D & Kurang baik \\
\hline $0-20$ & E & Sangat tidak baik \\
\hline
\end{tabular}

\section{Desain Penelitian}

Sesuai dengan jenis penelitian yang akan dilakukan yaitu penelitian tindakan kelas, maka penelitian ini memiliki tahap-tahap penelitian berupa siklus, yaitu terdiri dari dua siklus dan setiap siklus dilaksanakan dalam dua kali pertemuan. Setiap siklus dilaksanakan sesuai dengan perubahan yang ingin dicapai.

Secara garis besar terdapat empat tahapan yang lazim dilalui dalam penelitian tindakan kelas dalam setia siklus, yaitu:

1. Perencanaan,

2. Pelaksanaan,

3. Pengamatan,

4. Refleksi.

\section{HASIL PENELITIAN DAN PEMBAHASAN}

Penelitian yang dilakukan oleh penelit adalah penelitian tindakan kelas yang dilakukan dalam 2 siklus. Siklus yang dilaksanakan ini terdiri dari siklus I dan siklus II. Setiap siklus terdiri dari 1 kali pertemuan dan terdiri dari beberapa 
tahap, yaitu tahap perencanaan, tindakan, observasi, dan refleksi. Pada siklus II tahap-tahap yang dilakukan merupakan perbaikan pada siklus sebelumnya.

Hasil yang diperoleh pada penelitian ini terdiri dari data tes yang berupa nilai hasil belajar IPS dan data non tes yang terdiri dari hasil observasi menggunakan lembar aktivitas guru dan lembar aktivitas siswa. Hasil dari kedua penelitian pada kedua siklus tersebut digunakan untuk mengetahui peningkatan hasil belajar IPS dengan menggunakan model pembelajarankooperatif tipe Student Team Achievement (STAD)yang diperoleh siswa kelas IV SD Negeri055988 Gunung Ambat.

Pada perolehan nilai rata-rata hasil belajar IPS siswa kelas IV SD Negeri 055988 Gunung Ambat pada kondisi awal atau pra siklus (dilakukan prates) adalah 54,67. Selanjutnya diberikan tindakan melalui penerapan model pembelajarankooperatif tipe Student Team Achievement (STAD). Pada siklus I rata-rata hasil belajar IPS siswa kelas IV SD Negeri 055988 Gunung Ambat meningkat menjadi 59,83.

Selain itu, tingkat ketuntasan siswa juga mengalami peningkatan dari kondisi awal.Siswa yang mengalami tuntas belajar sama dengan atau di atas nilai KKM sebanyak 9 siswa atau 29,03\%.Pada siklus I setelah diberikan tindakan dengan menggunakan model pembelajaran kooperatif tipe Student Team Achievement (STAD) jumlah ketuntasan siswa meningkat menjadi 16 siswa atau $51,61 \%$. Sesuai dengan kriteria keberhasilan ketuntasan siswa yang ditetapkan peneliti yaitu sebesar $75 \%$ maka siklus I dirasa belum memenuhi kriteria keberhasilan yang diharapkan. Maka dilanjutkan pada siklus II dengan tindakan yang sama yaitu menggunakan penerapan model kooperatif tipe Student Team Achievement (STAD)pada pembelajaran IPS.

Pada siklus II ini, rata-rata hasil belajar IPS yang diperoleh siswa kelas IV meningkat menjadi 72,25 dan mengalami peningkatan jumlah ketuntasan siswa menjadi 27 siswa atau 87\%. Dengan demikian, ternyata model pembelajarankooperatif tipe Student Team Achievement (STAD)dapat meningkatkan hasil belajar Pendidikan IPS pada siswa kelas IV SD Negeri 055988 Gunung Ambat, itu terlihat dari hasil belajar yang diperoleh dari pra tindakan sampai dengan siklus II yang selalu mengalami peningkatan.

Selain hasil yang dipaparkan di atas, model pembelajaran kooperatif tipe Student Team Achievement (STAD) juga dapat meningkatkan aktivitas belajar guru dan siswa yang berlangsung di dalam kelas selama pembelajaran IPS berlangsung. Pada saat observasi awal yang dilakukan peneliti pada pembelajaran IPS. Pada saat proses pembelajaran pendidikan IPS berlangsung, guru menyampaikan materi dengan ceramah dan sesekali mengajukan pertanyaan kepada siswa. Guru terlihat kurang melibatkan siswa dalam melakukan proses pembelajaran dan cenderung mendominasi pembelajaran.

Selain itu siswa kurang memperhatikan saat guru menyampaikan materi pelajaran. Hal tersebut terlihat dengan adanya beberapa siswa yang melakukan aktifitas lain, menyanyi, berbicara dengan teman, menoleh ke arah teman, tiduran, menggambar, berdiri serta ada yang jalan-jalan saat proses pembelajaran berlangsung. Kemudian pada siklus I diterapkan model kooperatif tipe Student Team Achievement (STAD)terlihat adanya peningkatan partisipasi siswa pada setiap siklus, disebabkan selama proses pembelajaran guru menerapkan strategi 
atau langkah-langkah kegiatan dalam kooperatif tipe Student Team Achievement (STAD).

Pada siklus II, hampir semua siswa terlibat aktif baik secara fisik, mental dan emosional. Apalagi setelah guru menciptakan suasana kompetisi secara kelompok di kelas, masing-masing kelompok saling berlomba-lomba untuk menjadi kelompok yang terbaik. Karena dalam kompetisi tersebut, guru melihat keaktifan siswa dalam bertanya maupun menjawab pertanyaan, keaktifan dalam kelompok, kerjasama kelompok, kekompakkan kelompok dan hasil kerja kelompok. Hampir semua siswa aktif menjawab dan menanggapi pendapat temannya. Siswapun terlihat semakin antusias, senang, dan semangat dalam mengikuti pembelajaran.

Berdasarkan beberapa paparan di atas disimpulkan bahwa penelitian tindakan kelas yang dilakukan dapat meningkatkan hasil belajar siswa kelas IV SD Negeri 055988 Gunung Ambat dengan model pembelajarankooperatif tipe Student Team Achievement (STAD). Hal tersebut dibuktikan dengan adanya perubahan-perubahan yang terjadi pada hasil belajar siswa dalam pembelajaran IPS.

\section{PENUTUP}

\section{Simpulan}

Berdasarkan deskripsi dan pembahasan hasil penelitian yang telah dipaparkan pada bab sebelumnya, maka dapat diperoleh beberapa kesimpulan sebagai berikut:

1. Dengan penerapan model pembelajaran kooperatif tipe Student Team Achievement (STAD) dapat meningkatkan hasil belajar dalam pembelajaran IPS dengan pokok bahasan kenampakan alam dan budaya. Halini dapat dilihat dari persentase ketuntasan belajar secara klasikal dan nilai rata-rata siswa. Pada prates ketuntasan hasil belajar secara klasikal sebesar 29,03\% dengan rata-rata kelas 54,67, pada siklus I ketuntasan klasikal meninghkat menjadi 51,61\% dengan rata-rata 59,83, pada siklus II diperoleh ketuntasan klasikal sebesar 87,09\% dengan rata-rata kelas 72,25.

2. Keterampilan guru dalam pembelajaran IPS dengan pokok bahasan kenampakan alam dan budaya melalui model pembelajaran kooperatif tipe Student Team Achievement (STAD) mengalami peningkatan pada tiap siklusnya. Hal ini dapat dilihat berdasarkan rata-rata persentase skor aktivitas guru pada siklus I sebesar 56\% dengan kriteria cukup. Pada siklus II meningkat dengan perolehan $78 \%$ dengan kriteria baik.

3. Aktivitas siswa dalam pembelajaran IPS dengan pokok bahasan kenampakan alam dan budaya melalui model pembelajaran kooperatif tipe Student Team Achievement (STAD) mengalami peningkatan pada tiap siklusnya. Hal ini dapat dilihat berdasarkan rata-rata persentase skor aktivitas siswa pada siklus I sebesar 48,38 dengan kriteria kurang. Pada siklus II mengalami peningkatan dengan perolehan $76 \%$ dengan kriteria baik.

\section{Implikasi}

Berdasarkan hasil penelitian pada pembelajaran IPS dengan menggunakan mdel pembelajaran kooperatif tipe Student Team Achievement 
(STAD) menunjukkan adanya peningkatan hasil belajar siswa pada materi kenampakan alam dan budaya. Hal ini memberikan penjelasan bahwa penggunaan model pembelajaran yang tepat dalam proses pembelajaran dapat meningkatkan hasil belajar siswa. Oleh karena itu implikasi yang diperleh dari penelitian ini, yaitu.

1. Bagi siswa, pelaksanaan model pembelajaran kooperatif tipe Student Team Achievement (STAD) memberikan perubahan yang baik. Sebaian besar siswa yang awlnya cenderung pasif menjadi aktif saat diterapkan model pembelajaran kooperatif tipe Student Team Achievement (STAD). Hasil belajar siswa juga mengalami peningkatan, hal ini dibuktikan dengan nilai hasil belajar siswa secara individual maupun ketuntasan klasikal yang meningkat pada setiap siklus.

2. Bagi guru, pembelajaran melalui model pembelajaran kooperatif tipe Student Team Achievement (STAD) dalam kegiatan pembelajaran IPS bisa dijadikan alternatif pilihan pembelajaran dalam upaya meningkatkan hasil belajar siswa.

3. Bagi sekolah, penerapan model pembelajaran kooperatif tipe Student Team Achievement (STAD) yang dapat meningkatkan hasil belajar siswa mata pelajaran IPS dengan pokok bahasan kenampakan alam dan budaya dapat digunakan sebagai salah satu cara untuk meningkatkan mutu sekolah sebagai pembanding dengan sekolah lain secara umum.

\section{Saran}

Berdasarkan kesimpulan di atas, maka penulis memberikan saran yakni sebagai berikut:

1. Sebagai bahan masukan bagi sekolah untuk menggunakan model pembelajaran kooperatif tipe Student Team Achievement (STAD) dengan materi kenampakan alam dan budaya karena telah terbukti dapat meningkatkan hasil belajar siswa.

2. Kepada siswa khususnya siswa kelas IV SD Negeri 055988 Gunung Ambat diharapkan lebih giat belajar agar kemampuan membaca sisswa dapat meningkat sesuai dengan yang diharapkan, membangun pola interaksi dan kerjasama yang baik kapada sesama siswa maupun guru, supaya lebih aktif, kreatif serta giat dalam mengikuti pelajaran sehingga hasil belajar dapat tercapai dengan baik.

3. Bagi guru, guru perlu meningkatkan keterampilan dalam melaksanakan pembelajaran dengan menerapkan model pembelajaran inovatif dan memanfaatkan media yang sesuai dengan karakteristik siswa sehingga dapat miningkatkan profesionalisme guru dan dapat meningkatkan keaktifan siswa dalam proses pembelajaran.

4. Bagi peneliti lainnya, kiranya hasil penelitian tindakan kelas ini dapat dijadikan suatu refrensi dalam pengetahuan untuk menambah wawasan dan pemahaman mengenai penggunaan model pembelajaran dalam proses belajar mengajar.

\section{DAFTAR PUSTAKA}

Amri, Sofan. 2016. Pengembangan \& Model Pembelajaran dalam Kurikulum 2013. Jakarta: Prestasi Pustaka. 
Aqib, Zainal, dkk. 2014. Penelitian Tindakan Kelas untuk GuruSD, SLM, dan TK. Bandung: Yrama Widya.

Arikunto, Suharsimi. 2012. Dasar-Dasar Evaluasi Pendidikan. Jakarta: Bumi Aksara.

Budiningsih, Asri. 2009. Belajar dan Pembelajaran. Jakarta: Rinika Cipta.

Dimyati dan Mudjiono. 2013. Belajar \& Pembelajara. Jakarta: Rineka Cipta.

Gunawan, Rudi.2016. pendidikan IPS. Bandung:Alfabeta.

Hamalik, Oemar. 2014. Kurikulum dan Pembelajaran. Jakarta: PT Bumi Aksara. Isjoni. 2011. Cooperative Learning. Bandung: Alfabeta.

Istarani\& Pulungan. 2014. 58 Model Pembelajaran Inovatif. Medan: Media Persada.

Jihad, Asep dan Haris Abdul. 2012. Evaluasi Belajar. Yogyakarta: Multi Pressindo.

Khairani, Makmum. 2013. Psikologi Belajar.Yogyakarta: Aswaja Pressindo.

Lisa, Aryani. 2011. Upaya Peningkatan Hasil Belajar IPS Melalui Pembelajaran Kooperatif Tipe STAD (Student Teams Achievement Divisions) Kelas IV A MIN Yogyakarta II Tahun Ajaran 2011/2012. Yogyakarta: Universitas Negeri Yogyakarta.

Rusman. 2014. Model-Model Pembelajaran. Jakarta: Rajawali Pers.

Slameto. 2013. Belajar dan Faktor-Faktor yang Mempengaruhi. Jakarta: Rineka Cipta.

Sugiyono. 2006. Metode Penelitian Pendidikan. Bandung : Alfabeta.

Suprijono, Agus 2010. Cooperative Learning: Teori dan Aplikasi Paikem. Surabaya: Pustaka Belajar.

Susanto, Ahmad. 2016. Teori Belajar Pembelajaran di Sekolah Dasar. Jakarta: Prenada Media Group.

Tampubolon, Saur. 2014. Penelitian Tindakan Kelas Sebagai Pengembangan Profesi Pendidik dan Keilmuan. Jakarta: Penerbit Erlangga.

Trianto. 2009. Mendesain Model Pembelajaran Inovatif-Progresif. Jakarta: Kencana. . 2010. Mendisain Pembelajaran Inovatif-Progresif. Jakarta: Kencana. 